to t. a. line. On the costa beyond t. p. line a black patch from which proceeds the whitish subterminal line, almost parallel to the t. p. line and most strongly marked just before its junction with internal margin, almost forming a white crescent. A black terminal line. Fringes blackish, interrupted with paler.

Secondaries blackish with a chestnut tint, especially centrally. Below nearly uniform dark blackish gray with a slight chestnut tint; discal dot and t. p. line indicated in black. o moth. Abdomen extremely large, thorax small, legs slender, wings larger than usual, $6 \mathrm{~mm}$. long. Color white with a faint brownish tinge; down dense, especially on the under side of abdomen ; dorsum broadly dark cinereous, both on thorax and abdomen; wings faintly brownish; eyes black. Antennae shortly pectinated. Length $18 \mathrm{~mm}$; width of abdomen $12 \mathrm{~mm}$.

Habitat probably the Sierra Nevada of California. Recorded from Havilah, Kern Co., (Hy. Edw.) and Yosemite, Mariposa Co.

\title{
A LIST OF SOME OF THE CATALOGUES AND LOCAL LISTS OF NORTH AMERICAN COLEOPTERA.-III (R.-Z.).
}

\section{BY JOHN HAMILTON AND SAMUEL HENSHAW.}

I05 Rauterberg, Fr. Coleoptera of Wisconsin. (Proc. nat. hist. soc. Wis., 1885, p. I0-25.)

A list of 260 species and varieties of Cicindelidae and Carabidae with notes on the locality and time of occurrence.

Io6 Reed, E. B. Coleoptera taken in the neighborhood of London, Ont. (Can. ent., r869, v. r, p. 69-70.)

Number of families (31) genera (129) and species ( 180 ) found in the vicinity of London, Ont.; over 130 undetermined species additional to the above have been collected.

Io7 Reinecke, Ottomar. Additional list of Coleoptera. (Bull. Buff. soc. nat. sci., I 882 , v. 4, p. 55.$)$

N. Y. 44 .

Reinecke, Ottomar. See : ZESc'H, Frank H.

Io8 Ritchie, A. S. On the Coleoptera of the Island of Montreal. (Can. nat. and geol., 1869, ser. 2, v. 4, p. 27-36.) Separate: I I p.

215 species are listed from the Island of Montreal and 3I Canadian species taken outside the Island of Montreal.

Io9 Sahlberg, John. Coleoptera och medlemmar a Berings Sunds Amerikanska Hemiptera insamlade af Vega-expeditionens kust. (Vega-exped. vetens. iaktt., I $88_{5}$, bd. 4 , p. 59-7 I.)

16 species of Coleoptera are listed from Port Clarence, Grantley Harbor and Bay of Iman-Ruk. r io Saunders, W. Entomological notes during a trip to Saguenay. (Can. ent., I 868 , v. I, p. I I-I 3.)

18 species are listed with localities.

Savage, H. See : HaywArd, R.

I I Say, Thomas. Descriptions of coleopterous insects collected in the late expedition to the Rocky Mountains, performed by order of Mr. Calhoun, Secretary of War, under the command of Major Long. (Journ. acad. nat. sci. Phil., I823, v. 3 , p. I39-216; I 824 , p. $238-282 ; 298-331 ; 403-462 ;$ I 824 , v. 4 , p. 83-99.) Ed. Leconte, v. 2, p. 89-236.

Describes 354 species.

I 2 Schaupp, F. G. The Cicindelidae of the neighborhood of $\mathrm{New}$ York. (Bull. Brooklyn ent. soc., 1878 , v. I, p. 28.)

A list of 15 species with localities and times of appearance.

I 3 Schaupp, F. G. [Florida Coleoptera.] (Bull. Brooklyn ent. soc., I878, v. I, p. 34.)

Adds I 3 species to those listed by Schwarz.

II4 Schaupp, F. G. List of Carabidae found in the neighborhood of New York city. (Bull. Brooklyn ent. soc., $188_{3}$, v. 6 , p. 29-32; 7 I-72.)

212 species are listed with localities and times of appearance. 
II 5 Schmelter, H. Coleoptera of the neighborhood of New York. Chrysomelidae. (Bull. Brooklyn ent. soc., 1878, v. I, p. 55.)

96 species are listed.

i16 Schwarz, E. A. List of Coleoptera collected in Michigan in 1874 . (Psyche, I 876 , v. I, p. $145-\mathrm{r} 48$.)

ro2 species are cnumerated with notes and localities.

I 7 Schwarz, E. A. The Coleoptera of Florida. (Proc. Amer. philos. soc. 1878, v. I7, p. 353-47I.)

1386 species and varieties are listed on p. 434-469; the occurrence of more than 200 additional species is noted; many new species are described by the author and by Leconte.

I18 Schwarz, E. A. On a collection of Coleoptera from St. Augustine, Florida. (Proc. ent. soc. Washington, I889, v. I, p. I69-I7I.) Separate: $2 \mathrm{p}$.

General remarks on a collection of 600 species of Coleopter a collected in the vicinity of St. Augustine, Fla.; 2400 species known to occur in Florida.

Schwarz, E. A. See : Hubbard, H. G.

I 9 Smith, John B. List of Coleoptera collected by J. R. Spencer at Fort Churchill. (Rep. progr. Can. geol. surv.. 1882-83-9.4, I 885 , p. 62 DD.)

12 determined and 2 undetermined species are listed.

I20 Smith, J. B. Catalogue of insects found in New Jersey. (Final rep. state geologist, 1890, v. 2,486 p.)

2 r67 species and varieties of Coleoptera are listed on p. 69-271; localities and collectors are given when known.

I2 I Snow, F. H. List of Coleoptera collected in Colorado in June, July and August, I876, by the Kansas University scientific expedition. (Trans. Kans. acad. sci., I877, v. 5 , p. I 5-20.)

304 species and 12 varieties are enumerated; chiefly identified by Dr.J. L. Leconte. This list also appeared in the Kansas collegiate 1877 , v. 2 .

I22 Snow, F. H. The insects of Wallace county, Kansas. (Trans. Kans. acad. sci., I 878 , v. 6 , p. 6r-7o.)

Includes captures in Gove county; 3 i6 species and varieties of Coleoptera are listed on p. 62-7o with county localities of capture.

I 23 Snow, F. H. List of Coleoptera collected near Dome Rock, Platte Canon, Colorado, by the Kansas University scientific expedition for 1878 . (Trans. Kans. acad. sci., 1878. v. 6 , p. $75-77$.)

99 species and varieties are listed; a few are not fully identified.

I24 Snow, F. H. List of Coleoptera collected in Santa Fé Canon, N. M., by the Kansas University scientific expedition for 1880. (Trans. Kans. acad. sci., I88ı, v. 7, p. $70-77$.

237 species are listed.
I 25 Snow, F. H. Douglas county additions to the list of Kansas Coleoptera in 1879 and I880. (Trans. Kans. acad. sci., i88 I, v. 7, p. 78-79.)

144 species are listed.

I26 Snow, F. H. Lists of Lepidoptera and Coleoptera, collected in New Mexico by the Kansas University scientific expedition of $\mathrm{I} 88 \mathrm{r}$ and $\mathrm{I} 882$. (Trans. Kans. acad. sci., I 883, v. 8, p. $35-45$.)

525 species and varieties of Coleoptera are listed on p. 39-45; some are not fully determined.

I 27 Snow, F. H. Additions to the list of Kansas Coleoptera in $\mathrm{I} 88 \mathrm{r}$ and $\mathrm{I} 882$. ('Trans. Kans. acad. sci., I883, v. 8, p. $5^{8 .}$ )

49 species are listed; a few are not fully determined.

I28 Snow, F. H. Lists of Lepidoptera and Coleoptera collected in New Mexico by the Kansas University scientific expeditions of 1883 and 1884 . (Trans. Kans. acad. sci., I 885 , v. 9 , p. $65-69$.)

149 species and varieties of Coleoptera are listed on p. 66-69; some are not fully identified.

I29 Sprague, P. S. Insect fauna of Camel's Hump, Vt. (Arch. sci., i87r.)

55 species of Coleoptera are listed.

I3o Streoker, Herman. Coleoptera. ( $\Lambda \mathrm{n}$ nual rep. chief engineers for 1878,1878 , p. I864-1866 )

A list of 33 species collected in the San Juan region of Colorado.

I3 I Summers, S. V. List of Coleoptera of St. Louis county, Missouri. (Can. ent., I 873 , v. 5 , p. I $32-134:$ I $45^{-1} 47:$ 168-170 : I90I $92:$ I 874 , v. 6 , p. 52-55.)

$59 \mathrm{~S}$ species and varieties are listed; the list was not completed beyond the Colydiidae.

I32 Summers, S. V. Catalogue of the Coleoptera from the region of Lake Pontchartrain, La. (Bull. Buffalo soc. nat. sci., I 874, v. 2, p. 78-99.) Separate : 2 I p.

906 species and varieties are listed; a few are not fully identified.

I33 Taylor, George W. The entomology of Vancouver Island. Notes on seventy-six species of Cicindelidae and Carabidae collected near Victoria, Vancouver Island. (Can. ent., r886, v. I8, p. 34-37.)

Notes of capture and frequency are given.

I34 Townsend, C. H. 'T. A list of Coleoptera collected in Louisiana, on or south of parallel $30^{\circ}$. (Can. ent., i885, v. I7, p. 6673.)

I 3 species and varietıes are listed, with localities and notes of capture.

135 Townsend, Tyler. Contribution to a list of the Coleoptera of the lower peninsula of Michigan. (Psyche, I889, v. 5, p. 231-235.)

$\mathrm{r} 66$ species and varieties are listed; a few are not fully identified. 
r36 Uhler, P. R. Report upon the insects collected by P. R. Uhler during the explorations of 1875 , including monographs of the families Cydnidae and Saldae, and the $\mathrm{He}-$ miptera collected by A. S. Packard, Jr., M.D. (Bull. U. S. geol. and geog. surv., I877, v. 3, p. $355-475 ; 765-801$.)

95 species of Coleoptera from the plains and mountains of eastern Colorado are listed on p. 770-779.

137 Uhler, P. R. List of animals observed at Fort Wool, Va. (Studies biol. lab. Johns Hopkins Univ., I879, v. I, no. 3, p. I7-34.) 7 species of Coleoptera are recorded on p. 29-30.

I38 Ulke, Henry. List of species of Coleoptera, collected by Lieut. W. L. Carpenter, United States army, for the United States geological survey of Colorado, 1873. (Rep. U. S. geol. surv., [Hayden's 7 th rep.], 1874 , p. $567-57$ I.)

164 species are listed.

I39 Ulke, Henry. Report upon the collections of Coleoptera made in portions of Nevada, Utah, California, Colorado, New Mexico, and Arizona, during the years 1871 , I872, I 873 and 1874 . (Rep. geogr. and geol. expl. and surv. west rooth mer., I875, v. 5, Zoology, p. 809-827.)

$3 S_{2}$ species are listed with locality, date of capture, collector and range of habitat.

I 40 Walker, Francis. List of Coleoptera. Lord's Naturalist in Vancouver Island and British Columbia. London, ı 866, v. 2, p. 309-3 I I.

94 species are listed.

White, J. E. See : Brodre, W.

I4I Wickham, H. F. A list of the Coleoptera of Iowa City and vicinity. (Bull. lab. nat. hist. state Univ. Iowa, 1888, v. I, no. 1 , p. $8 \mathrm{I}-9^{2}$.

$86 \mathrm{I}$ species and 10 varieties are listed; a few species are not fully identified.

Wickham, H. F. See: OsBorn, Herbert.

I42 Zesch, Frank H. and Reinecke, Ottomar. List of the Coleoptera observed and collected in the vicinity of Buffalo. (Bull. Buffalo soc. nat. sci., I $88 \mathrm{I}$, v. 4, p. 2-I5.) Separate : 14 p.

${ }_{1424}$ species are listed.

\section{INDEX OF LOCALITIES.}

Alaska, 63, 69, 84, 85, 86, 87, 109.

Anticosti, 18 .

Argenteuil, Ca., 25.

Arizona, 64, 70, 74, 139 .

Athabaska Lake, 82.

Atlanta, Id., 78 .

Baltimore, Md., 83 .

Bay of Iman-Ruk, Alaska, Iog.

Belleville, Ont., 6, 7 .

Berings Straits, Iog.

Blanc Sablon, H. B. T., 51 .

Bonaventure, Quebec, 8.

British Columbia, I I, 43, 77, I40.

Buffalo, N. Y., I07, 142.

California, 46, 53, 62, 63, 64, 65, 66, 67, 7o, $71,76,84,86,139$.

California, Lower, 53,70 .

Camel's Hump, Vt., 38, 129.

Canada, 1, 4, 6, 7, 8, 12, 16, 17, 19, 23, 24, 25, $31,34,35,36,56,57,82,94,95,98$, 106, Io8, I Io.

Canada, Lower, 16, 17 .

Canada West, 4 .

Cape Chudleigh, H. B. T., 5 I.
Cape Digges, H. B. T., $5 \mathrm{I}$.

Caribou Island, Labrador, 91, 92 .

Churchill River, H. B. T., 8o, 82 .

Cincinnati, Ohio, 27, 28, 29.

Clemente Island, Cal., 53 .

Cliftondale, Mass., 39 .

Colorado, 13, 14, 15, 45, 50, 64, 76, 78, 79, I02, I21, 123, 130, I36, I38, г39.

Columbus, Ohio, 3 .

Cross Lake, Nelson River, H. B. T., 81, 82.

Cumberland House, Sask., 82.

Custer Co., Col., I5.

Davenport, Iowa, 99 .

Dome Rock, Col., I23.

Douglas County, Kansas, 125.

Florida, I13, I17, I1 8 .

Flying Post, Ont., 82.

Fort Bridger, Wy., Io3.

Churchill, H. B. T., I I9.

Simpson, N. W. T., 69.

Tejon, Cal., 66.

Whipple, Ariz., 74.

William, L. Sup., 6r.

Wool, Va., 137 . 
Frederic, Iowa, ror.

Frontera, 64 .

Gaspé, Quebec, 8, 23.

Gove County, Kansas, 22.

Grantley Harbor, Alaska, Io9.

Green Mountains, Vt., 38.

Green River Basin, Wy., Io3.

Grenville, Ca., 25.

Grimsby, Ont., 94, 95.

Guadalupe Island, 49 .

Hopedale, Labrador, 92.

Hudson's Bay Region, 26, 51, 80, 81, 82, I 19.

Idaho, $46,47,78,79$.

Indian Territory, 46 .

Iowa, 90, 99, 100, IOI, I4I.

Iowa City, I4I.

James Bay, 3 r.

Kabiuakagarni, Lake Superior, 82.

Kansas, 46, 58, 59, 64, 68, 71, 96, 97, 122, I 25,127 .

Kicking Horse, Pass, B. C., Ir.

Labrador, 91, 92, 93 .

Lake Huron, 82.

Pontchartrain, La., 132 .

Superior, 54, 61, 64, 82 .

Winnipeg, 8I, 82.

of the Woods, 82 .

Lincoln, C. W., 4.

London, Ont., Io6.

L'Orignal, Ca., 25.

Louisiana, I32, I34.

Lower Fort Garry, Manitoba, 8I.

Lycoming Co., Pa., 73.

Mackenzie River, N. W. T., 69.

Manitoba, 8r.

Maryland, 83.

Massachusetts, 37, 39 .

Mexico, 20, 64 .

Michigan, 54, I $16, \mathrm{I} 35$.

Michipicoten River, Lake Superior, 82.

Missinaibi House, Lake Superior, 82.

Missouri, 13r.

Montana, 46.

Monticello, Iowa, Ioo.

Montreal, Canada, 24, 108.

Mount Washington, N. H., 2.

Nebraska, 68.
Nelson River, 8o, 8r, 82.

Nelson River House, 83 .

Nevada, 46, 139 .

New England, 9, 48.

New Hampshire, 2, 32 .

New Jersey, 120.

New Mexico, 14, 45, 46, 68, 70, 71, 76, 124, 126, 128, 139 .

New York, I07, I1 2, I14, I 15, 142.

New York (City), II2, II4, 115.

North America, 3, 20, 21, 40, 41, 42, 60, 72, 88.

North West Territory, 69.

Nova Scotia, 55, 57 .

Norway House, Lake Winnipeg, 8I.

Oba, Lake Superior, 82.

Ohio, 27, 28, 29, 3 .

Ontario, 6, 7, 82, 94, 95, 106.

Oregon, 46, 62, 63, 67, 69, 7I.

Ottawa, Ca., 25, 34 .

Oxford House, H. B. T., 81, 82.

Pennsylvania, Io, 33, 73, 89 .

Philadelphia, Pa., Io.

Platte Canon, Col., r23.

Port Clarence, Alaska, Iog.

Portneuf, Quebec, 98 .

Quebec, 8, 16, 17, 19, 23, 98, г ro.

Reindeer Lake, H. B. R., 82.

Rimouski, Quebec, 8.

Rocky Mountains, II , 57, 78, 79, IO2, III.

Rouge, Ca., 25.

Russian America, 63, 69, 84, 85, 86, 87.

Saguenay, Quebec, Iro.

Saint Augustine, Fla., Ir8.

Lawrence, 8, 23.

Louis Co., Mo., I3r.

San Juan, Col., Izo.

Santa Fé Canon, N. Mex., I24.

Saskatchewan, 69, 82.

Sault de Ste. Marie, Lake Superior, 61, 82.

Sitkha, 84, 85.

Snake River, Wy., 47 .

Sonora, 65 .

Sorel, Ca., 24.

South Carolina, 52 .

Spring Lake Villa, Ut., IO4.

Stinkingwater River, Wy., Io3. 
Straits of Belle Isle, Labrador, 9I.

Stupart's Bay, H. B. T., 5 I.

Tennessee, 22.

Téton Basin, Id., 47.

Texas, 5, 64, 65, 7 o.

Thunder Bay, Lake Superior, 61, 82.

Utah, 46, 50, 71, 78, 104, I39.

Vancouver Island, 43, 75, 133, 140.

Vermont, 38, 129.

Victoria, Vanc., 43, 133 .

Virginia, 44, 137 .
Wallace Co., Kancas, 122.

Washington, 63, $7 \mathrm{I}$.

West Indies, 20.

White Mountains, N. H., 32.

Wind River Basin, Wy., to3.

Winnipeg, 43 .

Wisconsin, 105 .

Wyoming, 47, 78, 79, 103 .

Yellowstone Lake, $\mathrm{W}_{\mathrm{y}}$., 47 .

Yellowstone National Park, Wy., ro3.

York Factory, H. B. T., 8I.
Miscellaneous Notes. - A portion of volume I of Psyche which has long been out of print is now being reprinted and the volume can shortly be furnished for five dollars. Complete sets of Psyche or any one or more of the volumes can therefore be obtained at five dollars per volume. The number of copies on hand, however, is extremely limited and persons desiring to secure full sets or complete their series are advised to make early application to the treasurer, Samuel Henshaw, Cambridge, Mass.

A list of Labrador insects will be found in Dr. A. S. Packard's recent book The Labrador Coast (N. Y., Hodges) on pp. 385-396 and 446-447. He catalogues 233 species divided as follows: Arachnida II, Myriopoda I, Orthoptera I, Odonata 2, Hemiptera 4, Platyptera I, Plectoptera 3, Trichoptera 2, Coleoptera 63. Diptera i . Lepidoptera 108, and Hymenoptera 26. Notes of distribution and a few dates are added.

Entomologists should not overlook a holiday book of unusual interest for them, noting the out-door and in-door observations of a rambler who knows how to use both eyes and pencil, not to say pen. It is a volume by the artist William Hamilton Gibson, called "Sharp eyes, a rambler's calendar of fifty-two weeks among insects, birds, and flowers" (Harper's, \$5.00). Both text and illustrations, the latter on nearly every page, are by the same hand; better, more living pictures of our insects have never been given, especially where they are represented in flight, when they rival the pictures by Giacomelli; and yet all are "process cuts." The volume is excellent reading as well, and tells the stories of the lives of our common insects in a charming way. It is an admirable book to stimulate the young observer.

In a superb monograph of the trees which furnished the Baltic amber, with eighteen finely colored quarto plates, Conwentz of Danzig publishes some notices of amber insects, especially of such as were injurious to the species of Pinus which yielded amber; among other things he figures the borings of a beetle referred by Kolbe to Anthaxia and the larval burrows in the dead wood which Brischke looks upon as the work of a Sciara.

Dr. Juan Gundlach has just finished the printing of the second volume of his Entomologia Cubana which contains the Hymenoptera, Neuroptera, and Orthoptera.

Prof. John B. Smith's promised List of Lepidoptera of Boreal America has been issued by the American entomological society; it extends to 124 pages and includes 6020 nominal species, of which 640 are butterflies, 229 Sphingidae and Sesiidae, 590 the families allied to Lithosidae and Bombycidae, 1861 Noctuina, 65 I Geometrina, 634 Pyralidina, 429 Tortricina, and 986 Tineina. It follows the style of Grote's Check list of American moths. 

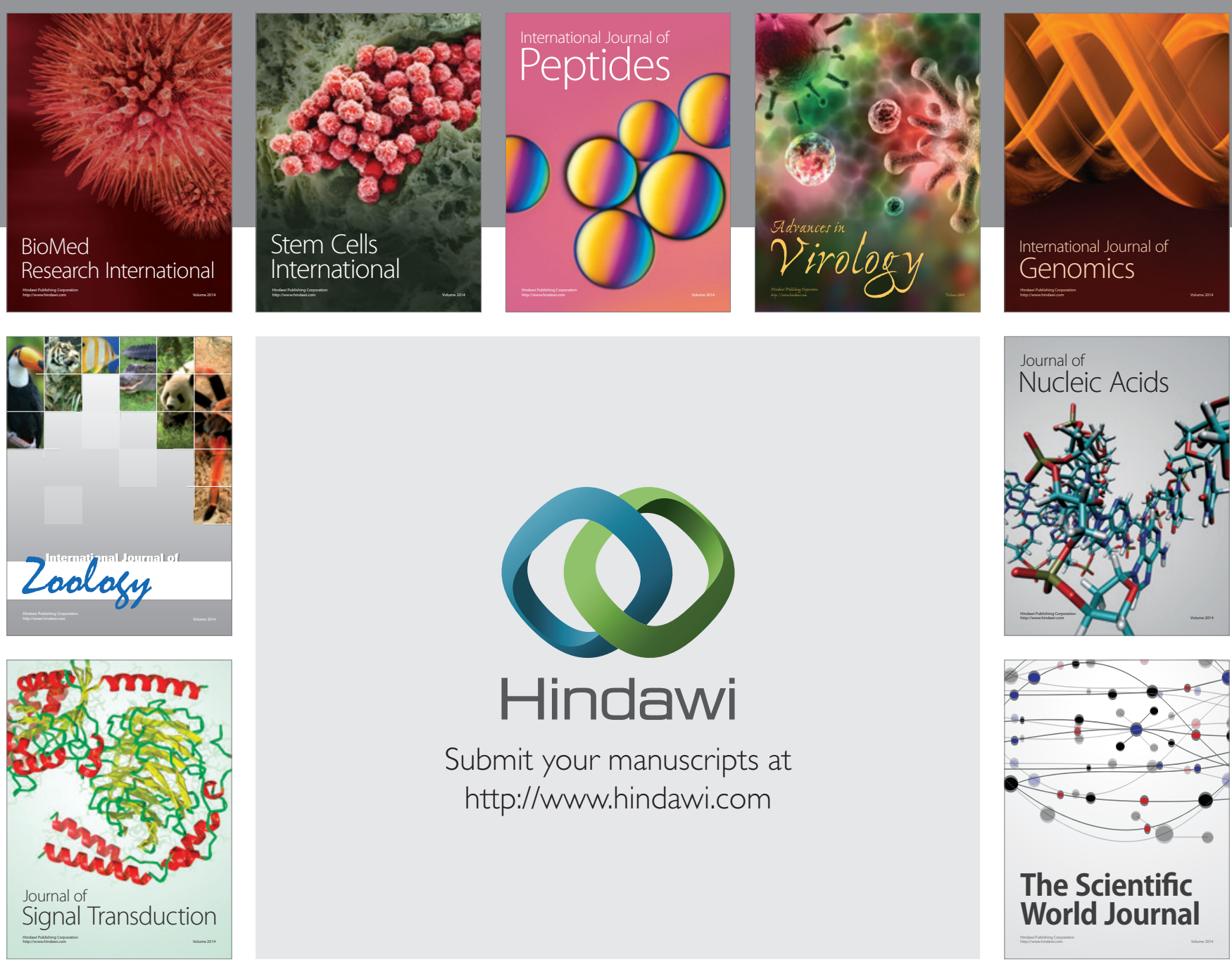

Submit your manuscripts at

http://www.hindawi.com
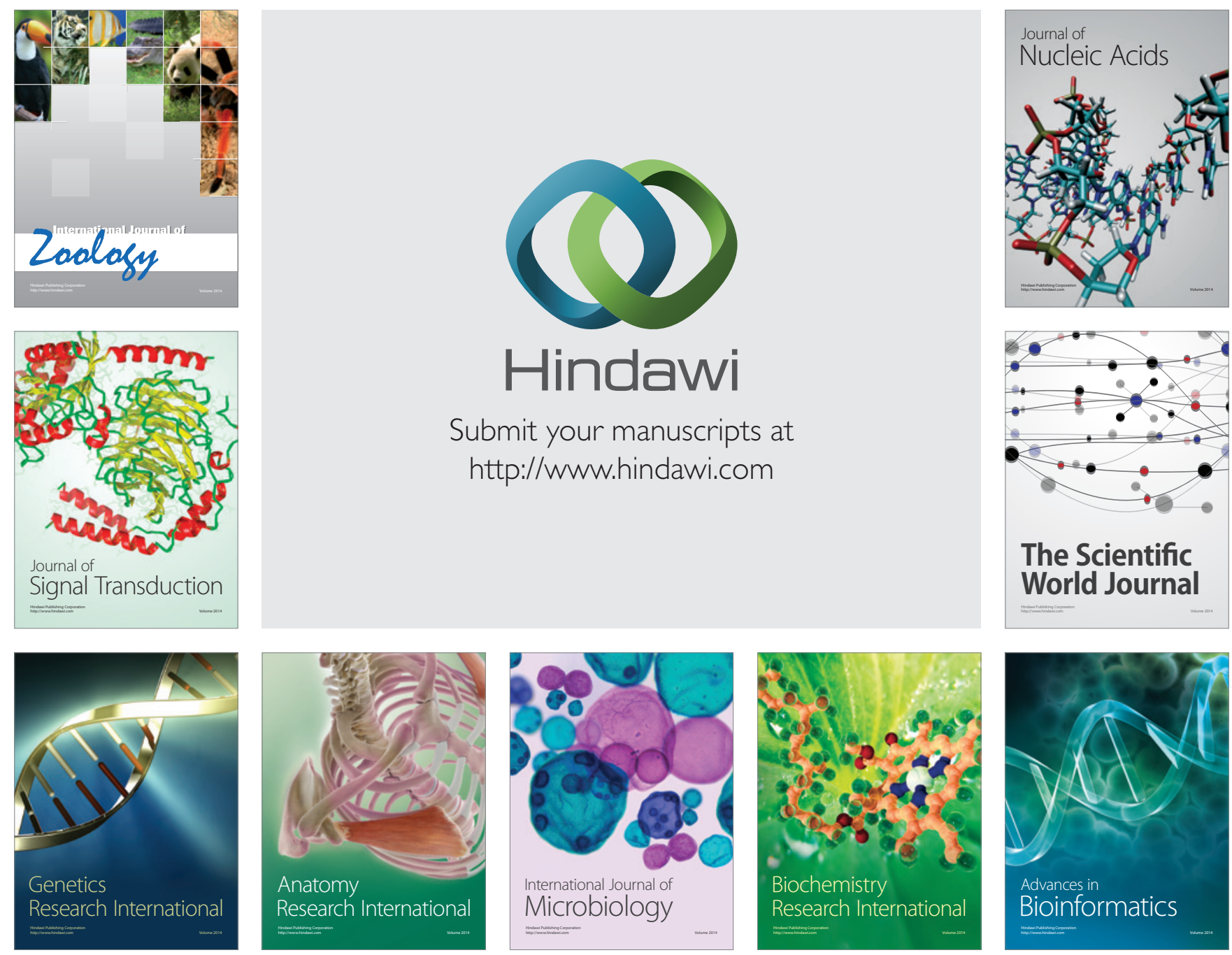

The Scientific World Journal
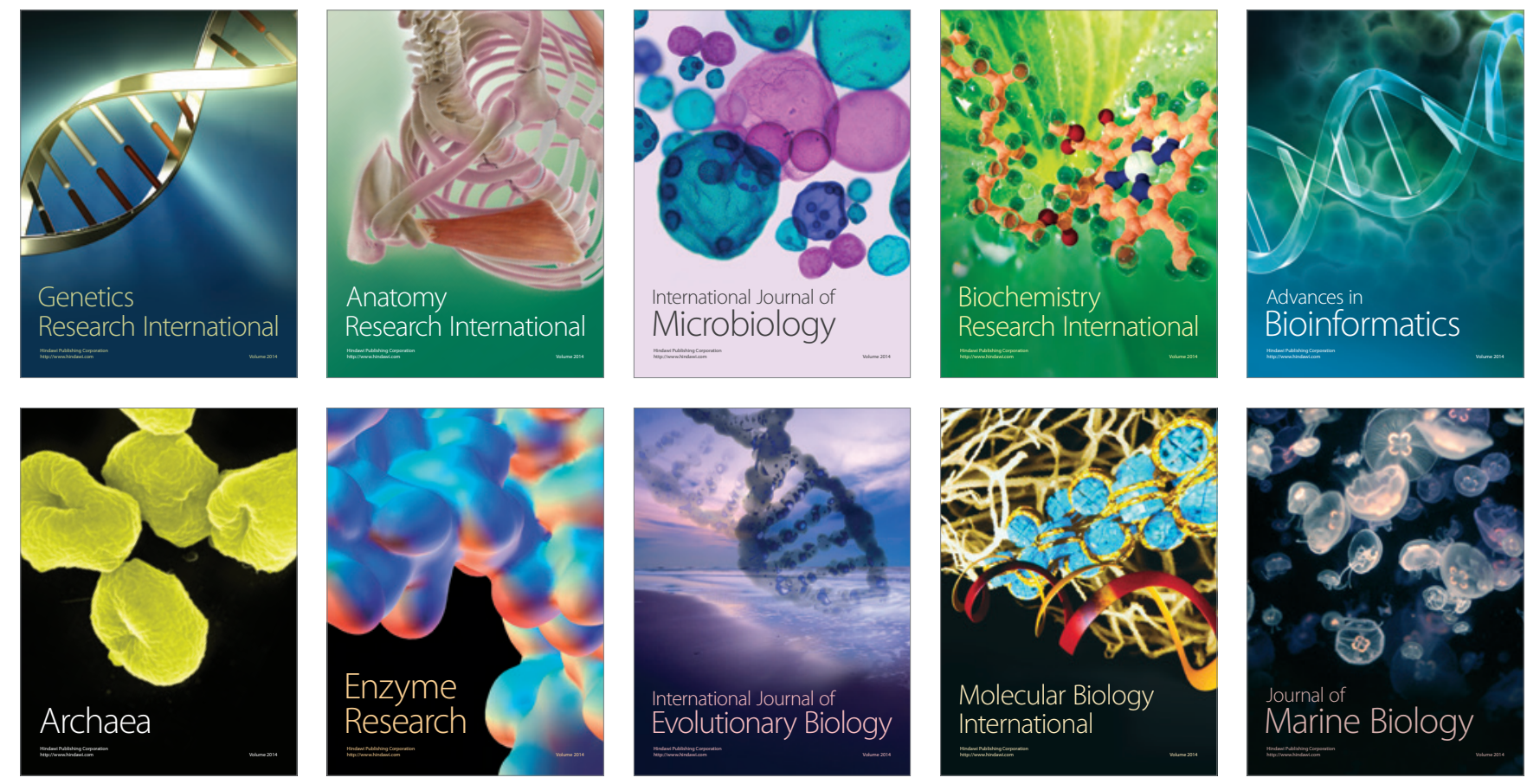